\title{
Mid-ocean ridge hydrothermal systems and the history of the oceans
}

\author{
DONALD J. DePAOLO ${ }^{1}$ AND DANIEl A. STOLPER ${ }^{1}$
}

${ }^{1}$ Dept. of Earth and Planetary Science, University of

California, Berkeley, CA 94720, djdepaolo@lbl.gov

Hydrothermal systems at mid-ocean ridge (MOR) spreading centers constitute one of the largest and most impactful geochemical phenomena on Earth. There is 65,000 $\mathrm{km}$ of MOR, and about $10 \%$ of the volume of the oceans flows through the hydrothermal systems every few million years. As seawater circulates through the igneous rocks of the seafloor, heat is released and there is extensive chemical exchange between the ocean and rocks. This chemical exchange affects the composition of seawater and may impact global climate; it also affects the mantle and island arc volcanism because the altered rocks of the oceanic crust are eventually subducted.

A key measure of seawater-rock exchange is ${ }^{87} \mathrm{Sr} /{ }^{86} \mathrm{Sr}$ ratios of both the hydrothermal fluids and altered seafloor rocks (e.g. Gillis et al., EPSL, 2005; Coogan, $\mathrm{G}^{3}$, 2009). The extent of $\mathrm{Sr}$ isotope exchange, in turn, is modulated by the chemistry of the oceans, most importantly by $\mathrm{pH}$ and $\mathrm{O}_{2}$ concentrations. These two variables affect the $\mathrm{Ca}, \mathrm{Sr}$, and $\mathrm{SO}_{4}$ concentrations of seawater, which can modify the behavior of $\mathrm{Sr}$ isotopes during hydrothermal MOR alteration (Antonelli et al., PNAS, 2017). Consequently, the behavior of Sr in modern systems may be different from that during most of Earth history when marine dissolved $\mathrm{O}_{2}$ and $\mathrm{pH}$ were lower.

A key controlling variable for the extent of $\mathrm{Sr}$ isotope exchange during hydrothermal circulation in MOR is the ratio of seawater $\mathrm{Ca}$ to $\mathrm{SO}_{4}$, which is about 0.35 today but may have been as high as 50 in the mid-Proterozoic and more than 100 in the Archean (Halevy and Bachan, Science, 2017; Planavsky et al., PNAS, 2012). We are using reactive transport modeling (ToughReact; Sonnenthal et al., 2014) to evaluate how changes in seawater $\mathrm{Ca} / \mathrm{SO}_{4}$, and correlative shifts in seawater $\mathrm{Sr}$ could affect $\mathrm{Sr}$ isotope exchange in MOR systems. Preliminary conclusions are that the ${ }^{87} \mathrm{Sr} /{ }^{86} \mathrm{Sr}$ of paleo-ocean floor rocks tended to be much more affected by seawater exchange than modern ocean floor rocks. This could explain the apparent decoupling of Archean and Early Proterozoic mantle evolution for $\mathrm{Sr}$ isotopes from that of $\mathrm{Nd}$ and Hf, especially as represented by island arc-type volcanic rocks. The role of seawater $\mathrm{SO}_{4}$ makes the effect partly dependent on atmospheric and ocean $\mathrm{O}_{2}$. Overall, the seafloor hydrothermal and weathering effects may provide an example of temporal changes in the (bio)geochemistry of Earth's surface affecting the geochemical evolution of the mantle. 